\title{
Ética e responsabilidade social
}

\section{Ethics and Social Responsibility}

\author{
Tânia Alves de Jesus \\ Instituto Superior de Contabilidade e Administração, Lisboa, Portugal \\ tajesus@iscal.ipl.pt \\ Manuela Sarmento \\ Academia Militar e Universidade Lusíada, Lisboa, Portugal \\ manuela.sarmento2@gmail.com \\ Manuela Duarte \\ Instituto Superior de Contabilidade e Administração, Lisboa, Portugal \\ manueladuarte@netcabo.pt
}

\begin{abstract}
Resumo
A Responsabilidade Social das Empresas (RSE) tem sido alvo de intenso e controverso debate, que tem levado à construção do seu conceito, de teorias e abordagens, relacionados também com a evolução do próprio conceito de empresa e com a aplicação da ética no contexto organizacional. Neste artigo investiga-se a ética enquanto filosofia moral e relaciona-se as orientações dos contabilistas em termos da fundamentação da ética com a sua atitude perante a RSE. Esta investigação permite identificar as orientações éticas: utilitarismo, egoísmo, absolutismo e justiça, sendo que a maior parte dos contabilistas revelam uma orientação ética fundada primariamente em princípios utilitaristas, considerando como justificação do compromisso ético das empresas e das ações daí decorrentes, os benefícios gerados para a empresa, bem como uma obrigação moral destas contribuírem para o bem-estar social. A visão da RSE é fundamentalmente consequentalista e atribui menos importância aos benefícios que a RSE pode trazer na diminuição de desigualdades sociais.
\end{abstract}

Palavras-chave: responsabilidade social das empresas; ética empresarial; ética.

\begin{abstract}
In the current context of severe economic and financial crisis worldwide, the integration of accounting and corporate social responsibility (CSR) is urgent, emphasizing an ethical dimension. This study relates ethics and CSR, by investigating the relationship between ethics and CSR orientation. This research identifies four ethical theories: utilitarian, selfishness, absolutism and justice. Most accountants reveal an ethical orientation based primarily on utilitarian principles considering that CSR benefits the company and that the company has a moral obligation to contribute to social well-being. The accountants consider less important the vision of CSR as a way to benefit and reduce social differences.
\end{abstract}

Keywords: corporate social responsibility; business ethics; ethics.

Dos Algarves: A Multidisciplinary e-Journal, $29-2017$.

ISBN 2182-5580 @ ESGHT - University of the Algarve, Portugal.

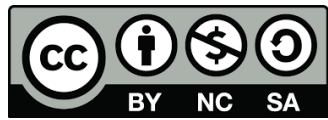

To cite this article: T. Jesus, M. Sarmento e M. Duarte (2017). Ética e responsabilidade social. Dos Algarves: A Multidisciplinary e-Journal, 29, 3-30. doi: 10.18089/DAMeJ.2017.29.1 


\section{Introdução}

A ordem estabelecida no mundo atual assenta, em grande medida, no desejo obsessivo de obtenção e consumo da maior quantidade possível de recursos e poder, trata como sinónimos o sucesso material e social e reacende a discussão da ética e da responsabilidade social em torno da gestão. A denominada "crise moral" e o clima global de falta de ética e de responsabilidade social da sociedade, em geral e das empresas em particular, aumentam o risco de práticas de contabilidade criativa e relato financeiro fraudulento, levantando, inevitavelmente a discussão da RSE (Responsabilidade Social das Empresas) e ética em torno da contabilidade.

O aparecimento de conceitos como a RSE veio contribuir para que haja organizações mais transparentes, nas quais é efetivo o compromisso ético. Contudo, a discussão da ética e da responsabilidade social em torno das empresas, da gestão e da contabilidade são áreas do saber que, apesar de terem sofrido grandes mudanças nas últimas décadas, encontram-se ainda pouco desenvolvidas e difusas.

Neste artigo investiga-se os fundamentos da ética enquanto filosofia moral e relacionase as orientações éticas dos contabilistas em termos da sua fundamentação ética com a sua atitude perante a RSE. Neste contexto, levantam-se as seguintes questões:

Q1: A responsabilidade social das empresas tem uma dimensão ética?

Q2: A atitude dos contabilistas perante a RSE assenta em fundamentações éticas?

\section{Responsabilidade social das empresas}

Embora a RSE esteja cada vez mais atual nos dias de hoje, este é um tema que tem vindo a ser abordado e estudado desde a década de 50 do século passado. Desde então, a RSE tem sido alvo de intenso e controverso debate que levou à construção do seu conceito relacionado com a grande evolução do próprio conceito de empresa e com a aplicação da ética no contexto organizacional.

O conceito de RSE foi, com a publicação do livro intitulado de Social responsabilities of the businessman de Howard Bowen, em 1953, inicialmente associado às obrigações e às ações voluntárias a assumir por parte dos empresários, e foram adaptadas, para além dos objetivos económicos e legais, aos objetivos e aos valores na sociedade (Carroll, 1999). Com esta associação, defende-se que deverá haver um aumento de RSE quando as empresas aumentam o seu poder na sociedade. Desde então, tem-se desenvolvido um intenso debate sobre a RSE. Este centra-se essencialmente nos fins que devem orientar as atividades das empresas, considerando a RSE como um desenvolvimento particular da responsabilidade social que abrange tanto empresas como organizações, instituições e indivíduos.

Surgiram noções de RSE, também designadas de visão liberal (Costa, 2005), que defendem que esta deve ter como objetivo exclusivo o lucro e que este possibilitará às empresas contribuir de forma adequada para a sociedade com a riqueza gerada e através do pagamento dos respetivos impostos. De acordo com esta perspetiva, a RSE esgota-se no objetivo único de gerar o lucro e enriquecer os proprietários das empresas. Destaca-se o célebre artigo de Friedman de 1970 onde o autor considera que a única responsabilidade social da empresa é para com os seus proprietários ou acionistas e traduz-se na maximização do lucro (v. Friedman, 1970). 
Uma das definições mais populares na literatura norte-americana sobre RSE foi a proposta apresentada por Carroll (1979), englobando responsabilidades e expectativas sociais, económicas, legais, éticas e discricionárias da sociedade inerentes ao desempenho social da empresa. Posteriormente, o modelo desenvolve-se para que as quatro componentes sejam inseridas numa pirâmide, denominando-se a responsabilidade discricionária de filantrópica, conforme apresentado na Figura 1.

De acordo com a perspetiva de ibid o melhor desempenho estará associado à empresa que, para além de cumprir com as suas responsabilidades económicas fundamentais e legais, também cumpre com os seus deveres éticos e realiza outras atividades filantrópicas. A configuração piramidal do modelo permite destacar as responsabilidades económicas como base que suporta todas as outras que, apesar de terem importância sequencial, deverão ser cumpridas simultaneamente. Por um lado, as responsabilidades éticas e filantrópicas remetem para comportamentos que, apesar de não serem exigidos por lei, são socialmente desejáveis e eticamente justificados indo ao encontro das expectativas criadas na sociedade quanto à atuação da empresa. Por outro lado, para além de se considerar que as responsabilidades económicas fazem parte integrante da RSE, aponta-se o lucro como uma condição não egoísta do capitalismo, sem o qual as restantes responsabilidades não podem ser cumpridas. Contudo, a importância reconhecida do modelo não impediu que lhe fossem apontadas diversas fragilidades (Almeida, 2010; Rego, Cunha, Costa, Gonçalves \& CabralCardoso, 2007).

Figura 1. Pirâmide da responsabilidade social da empresa

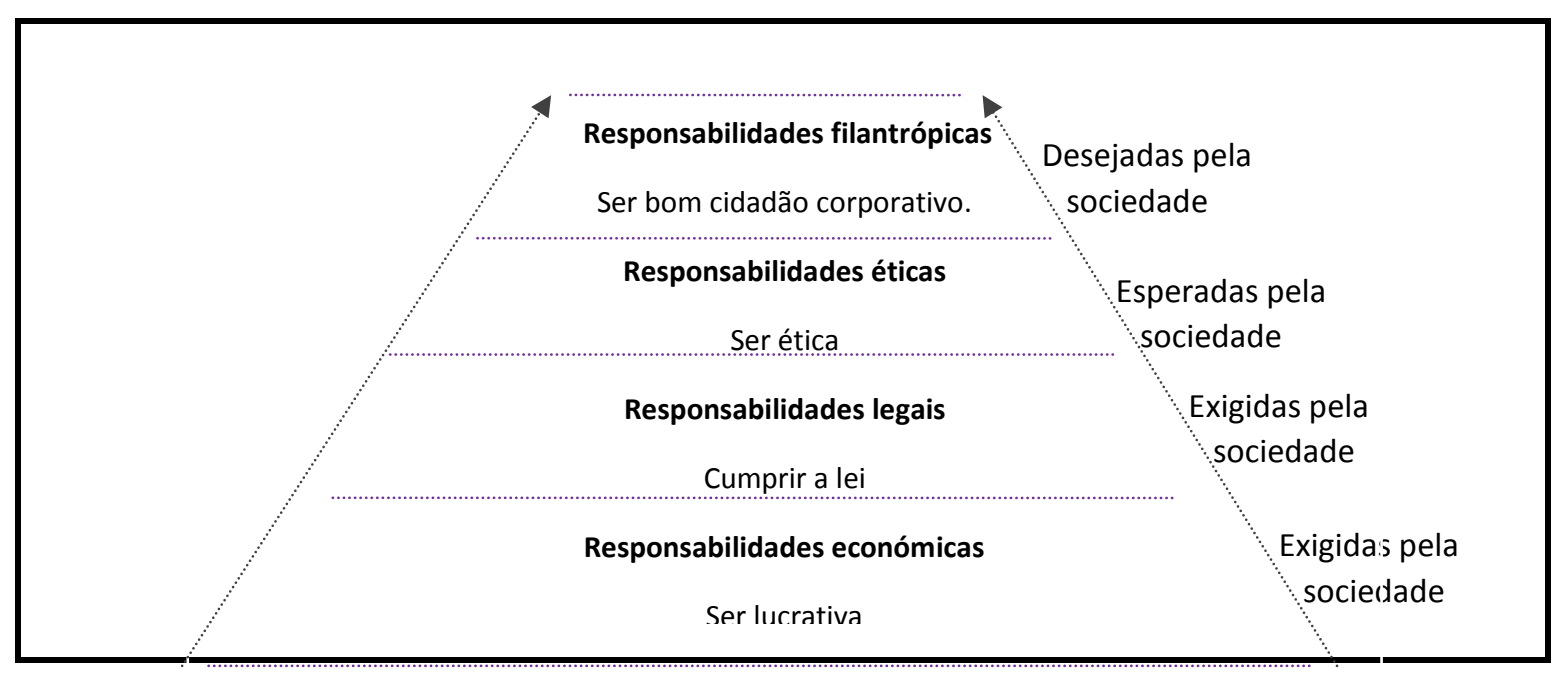

Fonte: Adaptado de Schwartz \& Carroll (2003: 504).

Destaca-se o cumprimento das responsabilidades filantrópicas que poderão colidir com as responsabilidades económicas. A filantropia pode ser apontada como uma manifestação do exercício da responsabilidade ética e o sentido ascendente e unidirecional do cumprimento das responsabilidades pode contrariar o princípio da equanimidade subjacente à responsabilidade social. Tendo em vista colmatar algumas das fragilidades do modelo piramidal, foi posteriormente proposto um modelo composto por três domínios (económico, legal e ético), com várias orientações empresariais, conforme apresentado na Figura 2.

Apesar de questionável, de acordo com o modelo dos três domínios, existem fronteiras nítidas que permitem classificar uma decisão como puramente económica, legal ou ética, 
existindo no entanto sete possibilidades de classificação. O melhor desempenho ocorrerá quando a empresa consegue conciliar de forma ideal os três domínios, o que nem sempre se verifica.

Figura 2. Modelo dos três domínios da SER

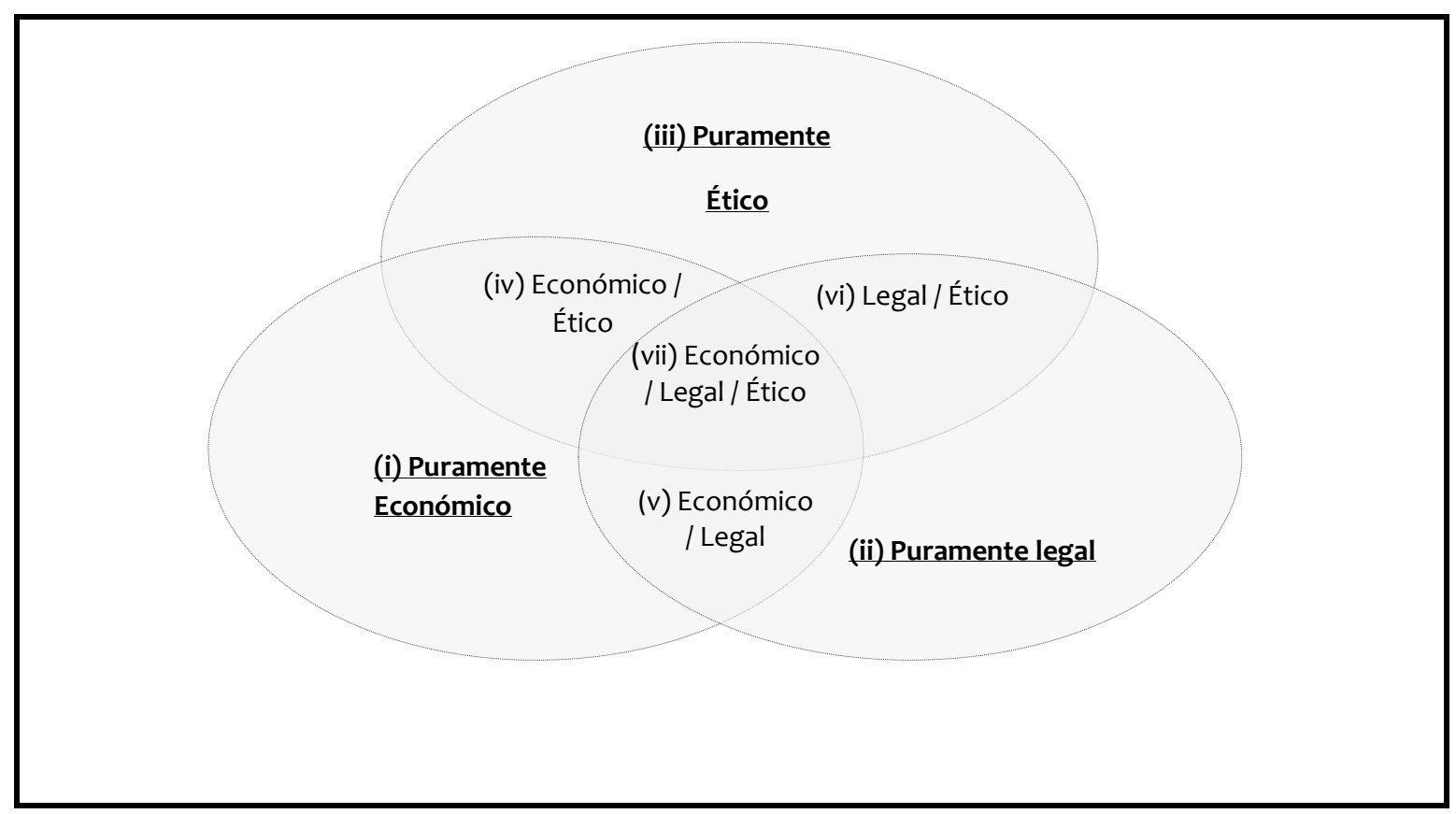

Fonte: Adaptado de Rego et al. (2007: 160) e Schwartz e Carroll (2003: 509).

Outras definições de RSE, como a da Comissão das Comunidades Europeias (2001), integram preocupações ambientais e sociais na interação da empresa com outras partes interessadas, numa base voluntária. Tal implica que se considere nas estratégias empresariais, as expectativas de todas as partes interessadas, assim como um princípio de inovação e melhoria continua. Outra área associada à RSE é a sustentabilidade e o desenvolvimento sustentável, assente em preocupações ambientais, económicas e sociais. Destaca-se o conceito de RSE proposto pela World Business Council for Sustainable Development (2000), como sendo um compromisso empresarial contínuo para um desenvolvimento económico sustentável melhorando a qualidade de vida dos seus colaboradores, famílias, comunidade e sociedade em geral. Deste modo, o desenvolvimento sustentável visa a satisfação das necessidades humanas, atuais e de gerações futuras, em harmonia e para que se garanta a conservação do meio ambiente. Defende-se uma estratégia de RSE a longo prazo baseada em integridade e valores sólidos como forma de trazer benefícios para as empresas e contribuir para o bem-estar da sociedade.

Quanto ao conceito de empresa, verifica-se que este se tem mostrado variável ao longo do tempo e de cultura para cultura. De acordo com Felix (2011), a empresa deixou de ser considerada um sistema de técnicas produtivas para passar a ser considerada cada vez mais como uma comunidade de pessoas. Assim, uma empresa é uma organização, que consiste num somatório de recursos maior que as suas partes e que vale também pelo Goodwill gerado internamente. Neste contexto, Felix (2011) defende que uma empresa não deverá ser um fim em sim mesma, mas sim um meio de desenvolvimento e de realização de pessoas. 
Conforme Rocha (2010), apesar de a empresa poder ser vista no sentido de empreendimento, como entidade física e como sociedade comercial, esta é uma instituição social como um família ou escola, que assegura a produção nas sociedades modernas de bens e serviços necessários. Verifica-se que não existe um conceito único de empresa nem este é especificamente jurídico. Tendo em conta que se relaciona num mercado interdependente de ligações entre pessoas e meio ambiente, atualmente a empresa moderna vê-se cada vez mais como um instrumento fundamental para satisfazer os múltiplos interesses e expectativas de uma sociedade complexa e em constante mudança. De acordo com Wu (2013), as partes interessadas exigem cada vez mais ter uma participação significativa nas decisões estratégicas. Surge, assim, a necessidade da empresa constantemente questionar as suas relações com as várias partes interessadas, de forma a responder com sucesso às suas expectativas legais, éticas e filantrópicas, ao mesmo tempo que esta se adapta e desenvolve para responder aos incentivos económicos (Sims, 2003). Conforme Minoja (2012), torna-se evidente que a empresa não terá capacidade para responder a todas as partes interessadas.

Logicamente, esta abordagem gera, no seio da empresa, preocupações a respeito das pessoas e suas liberdades. Leva a empresa a ser considerada como um centro de responsabilidade social, tanto para dentro como para fora, quando se corporiza como entidade moral e agindo de acordo com os interesses dos acionistas e das outras partes interessadas. Levanta-se, assim, uma importante dimensão ética.

Apesar de a empresa ter o papel de promover o bem-estar através da criação de riqueza, bens de qualidade e emprego, esta deverá respeitar o meio ambiente e não considerar a sua sobrevivência um fim em si e a qualquer custo. A empresa, enquanto cidadã, deverá assumir a sua responsabilidade na construção do futuro. Para esse fim, deve adotar uma postura ética empresarial assente em preocupações com a sustentabilidade, que Rocha (2010) denomina de Responsabilidade Social e que Carvalho (2011) refere como sendo "o sucesso económico com realização do homem ou o respeito ético diante do mundo com o qual a empresa se relaciona". Assim, surge a necessidade de dirigir o foco para a ética na empresa. Por outro lado, sendo as pessoas os principais agentes da empresa e que agem e interagem em seu nome, é expectável que a empresa espelhe os seus valores e saberes. De acordo com Regojo (2005), a ética é um exercício de liberdade impossível de ser imposto e que, na empresa, corresponde ao somatório da ética de todos os colaboradores. De forma concordante, Carvalho (2011) afirma que a ética se encontra nas pessoas que compõem a empresa e que quando praticada e aplicada pelos seus trabalhadores, constitui forma de corrigir as decisões e condutas inadequadas da empresa. Deste modo, o comportamento ético e socialmente responsável dos trabalhadores é muito importante para as organizações responderem e mudarem, de forma viável, as necessidades e expectativas das partes interessadas. Contudo, desde os anos 90 do século $\mathrm{XX}$, tem surgido na gestão uma visão crítica interna, cuja base é a Escola de Frankfurt, salientando que a perceção dos indivíduos, trabalhadores e consumidores, são condicionados de acordo com os parâmetros dos sistemas politico e económico e transformados por uma razão instrumentalizadora em “componentes de uma máquina" (Alvesson \& Wilmott, 1992). Caldeira (2009) salienta a pulsão tecnocrática que apresenta os gestores como depositários da racionalidade empresarial e cujas ações não se coadunam com a lógica da ética, remetendo as restantes partes interessadas para a posição de meros objetos ou meios. Argumenta, por um lado, que a posição de partida dos gestores, como qualquer outra parte interessada, está numa teia de 
interesses e objetivos muitas vezes conflituantes. Por outro lado, que é uma área demasiado poderosa e com fortes efeitos sobre os empregados, consumidores e cidadãos em geral para ser entendida como numa lógica unívoca de meios e fins. Destacam-se as investigações de Matthew, Bradley e Sutton (2016), que evidenciam que perante situações de grande monitorização os gestores tendem a avaliar as empresas como pobres em termos de ética e de Meredith, Bernardi e Bosco (2013), que mostram que as empresas serão mais éticas quanto maior o número de mulheres diretoras. Assim, a nova empresa deve ser entendida como tendo uma dimensão ético-política com objetos de estudo nascidos de contextos específicos, de relações de poder que podem ser transformados e desenvolvidos.

Neste contexto, a RSE passa pelo respeito ético diante das partes interessadas relacionando-se inevitavelmente com a ética na empresa. Contudo, constata-se que não tem havido ao longo do tempo uma definição consensual do conceito de RSE, apesar de este ter uma origem coexistente e comum com a ética na empresa.

Para além da ética, outro aspeto importante é a associação quase inevitável da RSE com outras áreas adjacentes. Inspirada pelas contribuições de Carroll (1979), Schwartz e Carroll (2003), elege-se a reinterpretação de RSE proposta por Almeida (2010). Esta assenta nas responsabilidades económicas, legais e éticas enquanto fontes que se estabelecem como princípios orientadores da ação das empresas e remete a responsabilidade filantrópica para o campo da ação da responsabilidade ética, conforme apresentado na Figura 3.

De acordo com Almeida (2010), a RSE pressupõe a ligação e comunicação entre os três tipos de compromissos sociais anteriormente referidos. Consequentemente, as ações da empresa socialmente responsáveis resultam das várias responsabilidades, considerando-se a dimensão ética da RSE a mais exigente, devido ao facto de ser imposta por responsabilidades morais e de consciência, não evidente nem consensual. Considera-se, assim, que a RSE encontra a sua justificação na responsabilidade ética tendo em conta que é através desta responsabilidade que a empresa pode agir de forma a beneficiar socialmente a sociedade, não assentando necessariamente no objetivo de gerar lucro.

Figura 3. Modelo das três fontes de responsabilidade social das empresas

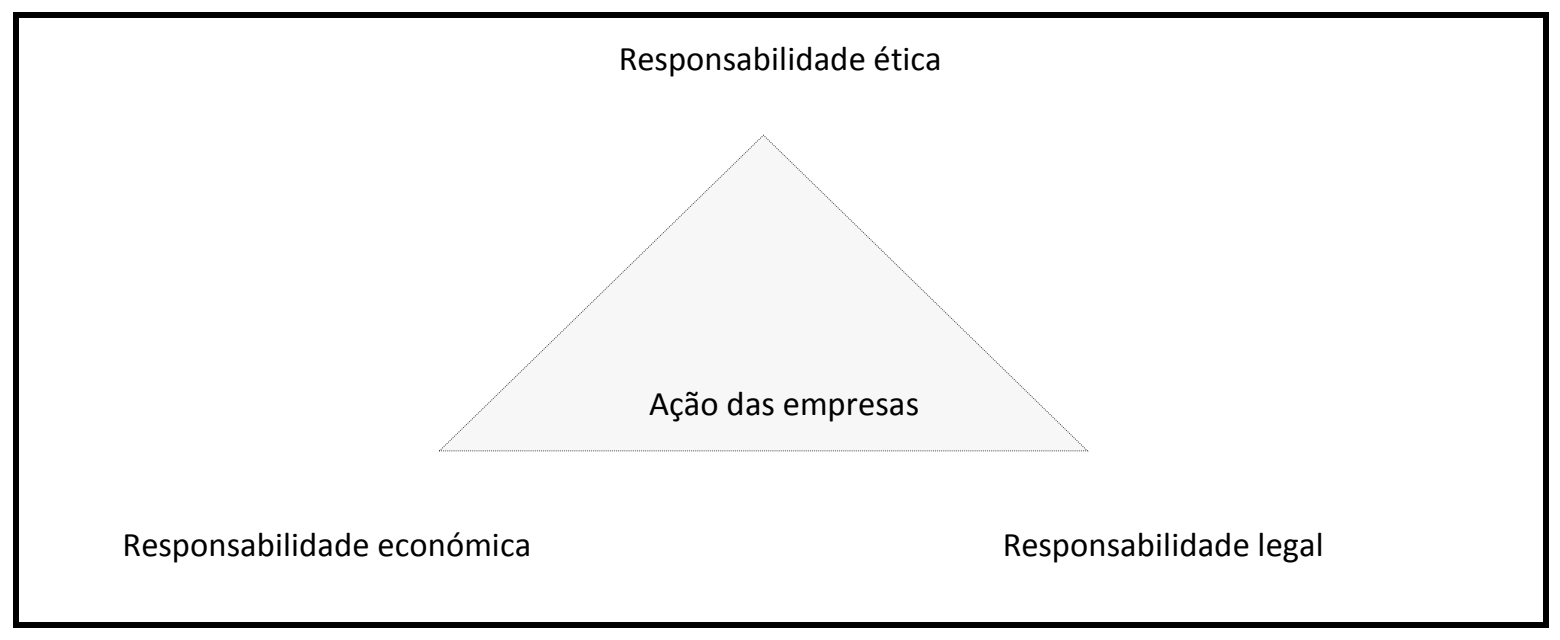

Fonte: Adaptado de Almeida (2010: 68).

Deste modo, e de acordo com a visão clássica, a RSE parece corresponder a uma gestão inovadora através da integração nas empresas de preocupações e responsabilidades sociais. 
Assim, os comportamentos empresariais deverão ser questionados e avaliados quanto à sua adequação em termos das responsabilidades das empresas perante a sociedade. A RSE vê-se, assim, dirigida pelos modelos desenvolvidos pelos indivíduos que integram as empresas, representando a relação que estes pretendem que a empresa desenvolva com a sociedade.

Considera-se que um dos maiores desafios da RSE é torná-la como parte integrante da cultura empresarial e do modelo estratégico da empresa, passando pela gestão ética no relacionamento entre as várias partes interessadas e a gestão socialmente responsável na promoção do bem-estar social. Referindo-se a ética empresarial ao estudo dos comportamentos e das decisões empresariais com impacto no bem-estar individual e social, verifica-se que o seu relacionamento com a RSE constitui uma base do campo da ética empresarial.

\section{Fundamentos éticos da responsabilidade social das empresas}

No seu sentido mais comum, o termo "ética" refere-se com frequência a um conjunto de regras que permitirão, supostamente, governar ou orientar o comportamento. Contudo, existem várias hipóteses de leitura da palavra ética e sua fundamentação, como o eudemonismo, hedonismo e kantismo, assim como de aplicação a âmbitos distintos da vida social, como é o caso da ética empresarial na sua relação com a ética cívica e económica.

\section{1. Ética como filosofia moral}

Apesar de a ética estar atualmente na moda, pelo menos em termos teóricos, existem várias hipóteses de leitura da palavra "ética" e sua fundamentação e aplicação a âmbitos distintos da vida social, como a ética aplicada ao contexto específico da atividade empresarial.

Quanto à leitura da palavra "ética", esta tem a sua origem em duas palavras gregas êthos e èthos referindo-se, prospectivamente, a morada ou carácter e hábitos ou costumes também na origem da tradução latina de mores, ou seja moral. Considera o carácter do homem como sendo onde este habita, algo exterior ao individual, voz da consciência ou voz divina e os hábitos e costumes ao nível dos comportamentos e do coletivo. Assim, ética e moral são dois termos equivalentes pela sua origem etimológica. No entanto, e de acordo com Cortina, Conill, Moratalla e Marzá (2005), têm vindo a configurar-se tecnicamente como duas formas de reflexão. Por um lado, a ética atinge a sua verdade enquanto parte da filosofia. Se a filosofia consiste num esforço conceptual dirigido a esclarecer os fins racionais da ação humana, a ética consiste no saber prático que visa orientar as leis do "dever-ser", as normas e conduta segundo as quais os seres humanos deverão idealmente agir. Verifica-se que a moralidade é inseparável da ética. A ética tem como objeto o fenómeno da moralidade, que engloba a realização de juízos sobre ações, da sua bondade ou maldade, é normativa e visa influenciar o ato de forma reflexiva, não se limitando a uma visão única. Por outro lado, a moral é um saber que pertence ao mundo da vida dos homens e o acompanha desde a sua origem. Relaciona-se com o "como se deve agir", enquanto a ética, consistindo numa teorização filosófica da ação, com o "porquê" de se dever agir.

No âmbito da filosofia em geral e da ética em particular, verificam-se diferentes perspetivas no mundo. Contrariamente ao que se verifica por exemplo no Budismo, que salienta a importância de não criar sofrimento a nenhum ser senciente, o pensamento ético na Grécia e, subsequentemente, na Europa e América do Norte limitava-se tradicionalmente 
ao contexto humano, expressando de forma limitada as preocupações pelo mundo natural. Atualmente e desde o século XX, nos sistemas éticos das culturas europeia e norteamericana, começaram a expandir-se de forma explícita a comunidade moral para além do ser humano. Ambientalistas éticos, tais como Leopold (1949), Rolston (1988) e Callicott (1989), vieram defender que o universo físico e, em particular, os seus vários ecossistemas têm simultaneamente uma posição moral e não deveriam ser explorados ou destruídos, assumindo assim uma posição contrária à visão que considera que o universo físico pode ser explorado pelos objetivos e para fins humanos (Callicott \& Frodeman, 2009).

No seu sentido mais comum, o termo "ética" refere-se com frequência a um conjunto de regras que permitirão, supostamente, governar ou orientar o comportamento, por vezes explicitado em códigos de ética ou de conduta. Contudo, e recuando mais de 2500 anos, a formulação de códigos de ética era deixada para os moralistas ou legisladores. Por um lado, a reflexão ética ocupava-se particularmente de aspetos mais gerais e abstratos, como o princípio ou princípios gerais que estão por detrás dos comportamentos éticos e dos comportamentos não éticos. Por outro lado, os filósofos preocupavam-se em descobrir a origem da ética e os seus fundamentos.

É comum na filosofia moral, separar-se as doutrinas teleológicas das doutrinas deontológicas. Por um lado, nas doutrinas teleológicas explicam-se os fenómenos segundo as suas finalidades, incluindo as teorias éticas consequentalistas que avaliam moralmente as consequências da ação humana tendo em conta o seu efeito. Por outro lado, nas doutrinas deontológicas, enquanto tratados dos deveres, incluem-se as teorias que pressupõem um imperativo moral prévio à avaliação dos efeitos da ação. A ética prudencial consiste numa visão para além das doutrinas teleológicas e deontológicas, na medida em que elege o carácter moral do homem como elemento central, considerando-o um ser racional. O seu âmbito da moral é o comportamento racional que passa por uma aprendizagem sobre como deliberar bem sobre os meios mais adequados para alcançar a felicidade do homem, refletindo sobre o seu carácter e nas suas circunstâncias e não em princípios ou regras universais de conduta.

Quanto à ética aplicada, consiste em utilizar as abordagens e resultados obtidos na sua fundamentação a âmbitos distintos da vida social, como à política, medicina, economia e empresa. Aplicando a ética à profissão do gestor ou contabilista, as questões éticas que se colocam são sobre os motivos de não se dever adotar práticas de contabilidade criativa e ignorar a RSE. Para tal, a fundamentação filosófica permitirá proporcionar um critério racional a aplicar, contudo, tendo em conta as especificidades das atividades empresariais $\mathrm{e}$ da sociedade.

\subsection{Orientação ética e responsabilidade social das empresas}

Existem muitos pontos de contacto entre a ética empresarial e a RSE. Quanto à ética empresarial, considera-se, por um lado, que as empresas têm um carácter próprio que influencia e é influenciado pelos seus vários elementos, logo detentoras de capacidade para atuar moralmente. Por outro lado, apesar de serem entidades com um certo grau de existência autónoma, que Ihes dá a liberdade e possibilidade de serem éticas, são impermanentes e determinadas pelo contexto com o qual se relacionam e do qual são interdependentes. Assim, tendo em conta que as sociedades atuais são compostas por 
organizações e que o sujeito moral não é apenas o indivíduo, mas o sujeito coletivo empresa, os desafios organizacionais e a criação de culturas organizacionais éticas constituem a causa de grandes questões da ética empresarial.

Quanto à relação da ética empresarial com a RSE, verifica-se profundos pontos de contacto em que a total sobreposição chega a ocorrer. Assim, considera-se que a origem da ética empresarial coincide com a da RSE na sua parte aplicada, ou seja, excluindo os fundamentos teóricos. Por um lado, com raízes filosóficas, a RSE condiciona a generalidade dos comportamentos empresariais, constituindo assim o eixo central de todo o campo da ética empresarial. Por outro lado a RSE permite analisar a forma como a empresa atinge os seus objetivos, os meios que utiliza e o bem-estar que proporciona à sua volta. Assim, e relacionando a ética com a RSE, não se questiona o objetivo de as empresas serem lucrativas, mas sim a forma como estas atuam na sociedade.

Figura 4. Correntes de pensamento ético

\begin{tabular}{|c|c|c|}
\hline \multicolumn{2}{|l|}{} & Foco \\
\hline Abordagem & Utilitarismo & Acção ideal \\
\hline Escolas clássicas & Justiça & \\
\hline Macro nível & Virtudes & Caráter ideal \\
\hline Micro nível & & \\
\hline
\end{tabular}

Fonte: Almeida (2010: 131).

No que se refere à fundamentação teórica da RSE, optou-se pelo procedimento adotado por Almeida (2010), que aborda a RSE através de pensamentos éticos das teorias éticas mais relevantes no campo da ética aplicada à gestão da empresa, conforme apresentado na Figura 4 . 
Tabela 1. A empresa segundo a ética teleológica, deontológica e das virtudes

\begin{tabular}{|c|c|c|c|}
\hline Teoria Ética & Missão & Perspetiva & $\begin{array}{l}\text { Responsabilidade social } \\
\text { das Empresas }\end{array}$ \\
\hline Utilitarismo & $\begin{array}{l}\text { Contribuir para o } \\
\text { desenvolvimento económico e } \\
\text { social da sociedade da qual } \\
\text { depende e é uma célula } \\
\text { fundamental. } \\
\text { Ser lucrativa é um objetivo } \\
\text { intermediário que pode ser } \\
\text { sacrificado. }\end{array}$ & $\begin{array}{l}\text { Orientação para as várias } \\
\text { partes interessadas, } \\
\text { satisfazendo carências e } \\
\text { necessidades de múltiplos } \\
\text { grupos sociais, incluindo } \\
\text { acionistas, empregados, } \\
\text { parceiros económicos e a } \\
\text { sociedade em geral. }\end{array}$ & $\begin{array}{l}\text { Envolvimento em } \\
\text { projetos que promovam o } \\
\text { progresso social mesmo } \\
\text { que obriguem a desvios } \\
\text { de recursos da atividade } \\
\text { económica principal. }\end{array}$ \\
\hline Egoísmo & $\begin{array}{l}\text { Satisfazer necessidades da } \\
\text { sociedade por meio da } \\
\text { produção de bens e prestação } \\
\text { de serviços, sendo o lucro o seu } \\
\text { objetivo principal. }\end{array}$ & $\begin{array}{l}\text { Orientação para o acionista, } \\
\text { satisfazendo as suas } \\
\text { necessidades, cumprindo a } \\
\text { lei e respeitando os direitos } \\
\text { individuais. }\end{array}$ & $\begin{array}{l}\text { Contribuição social por } \\
\text { meio da atividade } \\
\text { económica e do } \\
\text { pagamento de impostos. }\end{array}$ \\
\hline Absolutismo & $\begin{array}{l}\text { Contribuir para os fins das } \\
\text { pessoas em geral através de } \\
\text { práticas morais motivadas por } \\
\text { um sentido racional de dever, } \\
\text { respeitando as liberdades } \\
\text { positivas e negativas das } \\
\text { pessoas. }\end{array}$ & $\begin{array}{l}\text { Orientação para todas as } \\
\text { partes interessadas, } \\
\text { considerando todos os } \\
\text { interesses como iguais, } \\
\text { devendo todos participar na } \\
\text { definição das regras e } \\
\text { políticas empresariais. }\end{array}$ & $\begin{array}{l}\text { Dever genuíno de } \\
\text { beneficiar a sociedade, de } \\
\text { auxílio e de solidariedade, } \\
\text { sem preocupação com a } \\
\text { Natureza, considerando-a } \\
\text { como meio para os fins } \\
\text { humanos. }\end{array}$ \\
\hline Justiça & $\begin{array}{l}\text { Contribuir com base em } \\
\text { princípios de justiça social } \\
\text { distributiva, assente num } \\
\text { modelo capitalista que defenda } \\
\text { a liberdade alheia. }\end{array}$ & $\begin{array}{l}\text { Orientação para todas as } \\
\text { partes interessadas, } \\
\text { favorecendo os mais } \\
\text { carenciados em caso de } \\
\text { desigualdade. }\end{array}$ & $\begin{array}{l}\text { Controlo rigoroso do } \\
\text { impacto ambiental. } \\
\text { Obrigação moral de } \\
\text { justiça. } \\
\text { Evitar, minimizar e corrigir } \\
\text { efeitos da sua ação que } \\
\text { comprometam a } \\
\text { liberdade alheia. }\end{array}$ \\
\hline Virtudes & $\begin{array}{l}\text { Agir como se estivesse amando } \\
\text { com motivações assentes em } \\
\text { entusiamo, confiança, sentido } \\
\text { de justiça, compaixão, respeito } \\
\text { e paciência, sendo as virtudes } \\
\text { que geram comportamentos } \\
\text { competitivos menos } \\
\text { necessárias e prevalecendo as } \\
\text { pessoas sobre os lucros. }\end{array}$ & $\begin{array}{l}\text { Orientação para os agentes } \\
\text { de decisão ou dirigentes } \\
\text { favorecendo o seu } \\
\text { autodesenvolvimento. }\end{array}$ & $\begin{array}{l}\text { Agente ativo de bem } \\
\text { estar social, através de } \\
\text { atividades filantrópicas } \\
\text { respeitando o meio termo } \\
\text { e o respeito por leis } \\
\text { universais impostas. }\end{array}$ \\
\hline
\end{tabular}

Fonte: Adaptado de Almeida (2010).

Considerou-se o utilitarismo de Mill (v. Simões, 2016) e o egoísmo ético, a ética de Kant ([1785] 2015), a teoria da justiça de Rawls (1971) e o pensamento de Aristóteles ([1837] 2009) sobre as virtudes humanas abordando as suas implicações no plano organizacional, conforme apresentado na tabela 1.

Quanto às implicações do utilitarismo no plano organizacional, estas podem traduzir-se na maximização da eficiência, ou seja, na obtenção da máxima produção com o menor número de recursos tendo em vista a maximização do lucro. Contudo, a eficiência é apenas um valor instrumental enquanto meio para se atingir um determinado fim. Assim, colocam-se dificuldades sobre a mensuração da utilidade. Por um lado, o utilitarismo poderá não 
considerar um tratamento inadmissível de uma minoria ou permitir práticas de contabilidade criativa se num dado contexto, em detrimento da falta de transparência, beneficiar os detentores do capital e restantes partes interessadas, incluindo a comunidade local. Neste contexto, Rego et al. (2007) e Almeida (2010) distinguem dois tipos de utilitarismo, o dos atos e o das regras ou normas. Quanto ao utilitarismo dos atos, corresponde à versão original do utilitarismo e considera que devem ser praticados os atos que contribuem para o maior bem para a maior quantidade de pessoas, admite a existência de regras que contudo poderão não ser adotadas sempre que as circunstancias o aconselhem. $O$ utilitarismo considera regras de aplicação universal avaliadas e definidas em função das consequências. Neste contexto percebe-se a complexidade e as limitações das teorias utilitaristas. A ética é, muitas vezes, vista como um fonte de sucesso comercial e financeiro. Contudo, os seus princípios permitem sustentar uma postura de responsabilidade empresarial que exceda o objetivo das empresas serem estritamente lucrativas. Assim, tendo em conta que os seus princípios defendem a validade ética do sacrifício parcial ou temporário do lucro, que a RSE deverá exceder o estrito fim lucrativo e que é associada a uma vida boa para todos, representa, conforme Almeida (2010), um fundamento ético indiscutível de cidadania empresarial.

Quanto às implicações do egoísmo ético no plano organizacional, verifica-se que é no meio empresarial que o egoísmo ético tem mais adesão, pois perante um mercado competitivo de livre concorrência é expectável por muitos que as empresas operem em função dos seus interesses, considerando principalmente que com o seu êxito económico estarão diretamente a contribuir para o bem-estar social. Os gestores agem em função dos seus próprios interesses e dos das empresas, procurando satisfazer as suas próprias necessidades e zelar pelas suas carreiras. Deste modo, as transações comerciais na vida empresarial não conduzirão a conflitos mas antes a um resultado favorável, trazendo a maiores benefícios para o maior número de pessoas, dentro de um quadro competitivo. Conforme abordado por Rego et al. (2007), esta doutrina, apesar de ter grande recetividade no mundo dos negócios e de ser um fundamento teórico da economia de mercado, colide com a generalidade das doutrinas éticas, sendo também contestada pelos seus efeitos perversos.

Quanto às implicações da ética kantiana no plano organizacional, considera-se a empresa com a finalidade de contribuir para os fins dos seus semelhantes, através de práticas morais baseadas na coerência lógica e respeitando as liberdades positivas e negativas das pessoas e as necessidades de todas as partes interessadas como iguais, devendo todos participar na definição das regras e políticas empresariais. No âmbito da RSE, as empresas devem praticar ações pelo dever genuíno de beneficiar a sociedade através do auxílio. Contudo, rejeita as emoções e os sentimentos como motivos válidos para o comportamento moral, não referindo qualquer preocupação em especial com a Natureza, considerando-a como meio para os fins humanos.

Quanto às implicações da justiça como equidade na organização e de acordo com Rawls (1971), a justiça defende o papel da empresa assente em princípios sociais distributivos conforme um modelo capitalista, mas que, em termos de RSE, pressupõe um controlo rigoroso do impacto ambiental e da obrigação moral de justiça. A empresa deverá evitar, minimizar e corrigir os efeitos da sua ação que comprometam a liberdade alheia, encontrando-se orientada para todas as partes interessadas mas favorecendo, em caso de desigualdade, os mais carenciados. 
Quanto às implicações das virtudes aristotélicas no plano organizacional, destacam-se as virtudes Magnanimidade, Magnificência, Liberdade e Justa Indignação. Por um lado, se uma empresa cultivar virtudes morais no contexto empresarial, é uma forma adequada desta se aproximar dessa grandeza. Por outro lado, e de acordo com Almeida (2010), questiona-se a nobreza e a sabedoria associadas, dádiva dos seus recursos, que possibilitem o bem-estar e desenvolvimento social. Neste contexto, a virtude da liberdade pressupõe que as empresas e os seus dirigentes encontrem um ponto de equilíbrio, de forma a atribuírem as riquezas certas às pessoas certas. Ainda, uma empresa pode distinguir-se de outra por se envolver em ações sociais com objetivos estratégicos ou por se envolver por motivos de justa indignação, sensibilidade que resulta numa solidariedade cativa perante o sofrimento alheio. Assim, de acordo com Almeida (2010) esta abordagem da ética empresarial desvaloriza o papel dos princípios universais para determinar as ações aceitáveis e para se centrar nas virtudes morais que o carácter dos dirigentes e funcionários devem possuir, pressupondo que estas terão impacto necessariamente na natureza das práticas empresariais. Fazendo a ponte com a RSE, os princípios de RSE deverão implicar necessariamente uma transformação nas empresas para que estas atuem motivadas pela justa indignação e conscientes da nobreza associada à liberdade. Assim, e como consequência, os princípios de RSE revelam o carácter virtuoso dos membros que concebem a empresa como uma comunidade dentro de outra comunidade, caracterizada por relações de interdependência entre elas.

Verifica-se, assim, que os vários fundamentos teóricos apresentam aspetos em comum nos princípios gerais da RSE e que estes têm raízes filosóficas que permitem, na maior parte dos casos, condicionar a generalidade dos comportamentos empresariais e assim constituir o eixo central de todo o campo da ética empresarial. De forma concordante com Almeida (2010), estes fundamentos parecem originar o aperfeiçoamento da consciência, contribuindo para uma relação humana mais justa e solidária, sendo este argumento favorável a uma visão da RSE, para além da persecução do lucro e do cumprimento das leis.

\section{Metodologia}

\subsection{População e amostra}

Em relação à dimensão da amostra, esta atendeu a um conjunto de etapas. De um universo total de 55 empresas cotadas na Euronext Lisboa, foram retiradas as empresas financeiras e SAD (sociedades anónimas desportivas), devido às suas características e particularidades face às restantes empresas, ficando com um $\mathrm{N}=37$ empresas, correspondendo a $\sim 300$ contabilistas. Para um nível de confiança de $95 \%$ e um erro amostral de $\pm 5 \%$, o cálculo para populações finitas $(\mathrm{N}=300)$, apresentou uma dimensão de amostra de 168 contabilistas. Dos 168 contabilistas contactados para este estudo entre os anos de 2013 e 2014 obteve-se uma taxa de resposta de $70 \%$ do total. Estes resultados deram sustentação para prosseguir com as restantes análises. Quanto à caracterização dos inquiridos, verifica-se que os contabilistas têm em média entre 10 a 20 anos de experiência profissional em contabilidade e que estes se situam, na sua maioria, entre os 30 e os 45 anos. Os contabilistas do género masculino representam $51 \%$ dos inquiridos e estes são na maior parte Contabilistas Certificados. No que diz respeito ao nível das habilitações literárias, pode observar-se que a maioria dos respondentes possui licenciatura (ver Figura 5). 
Figura 5. Caracterização da amostra

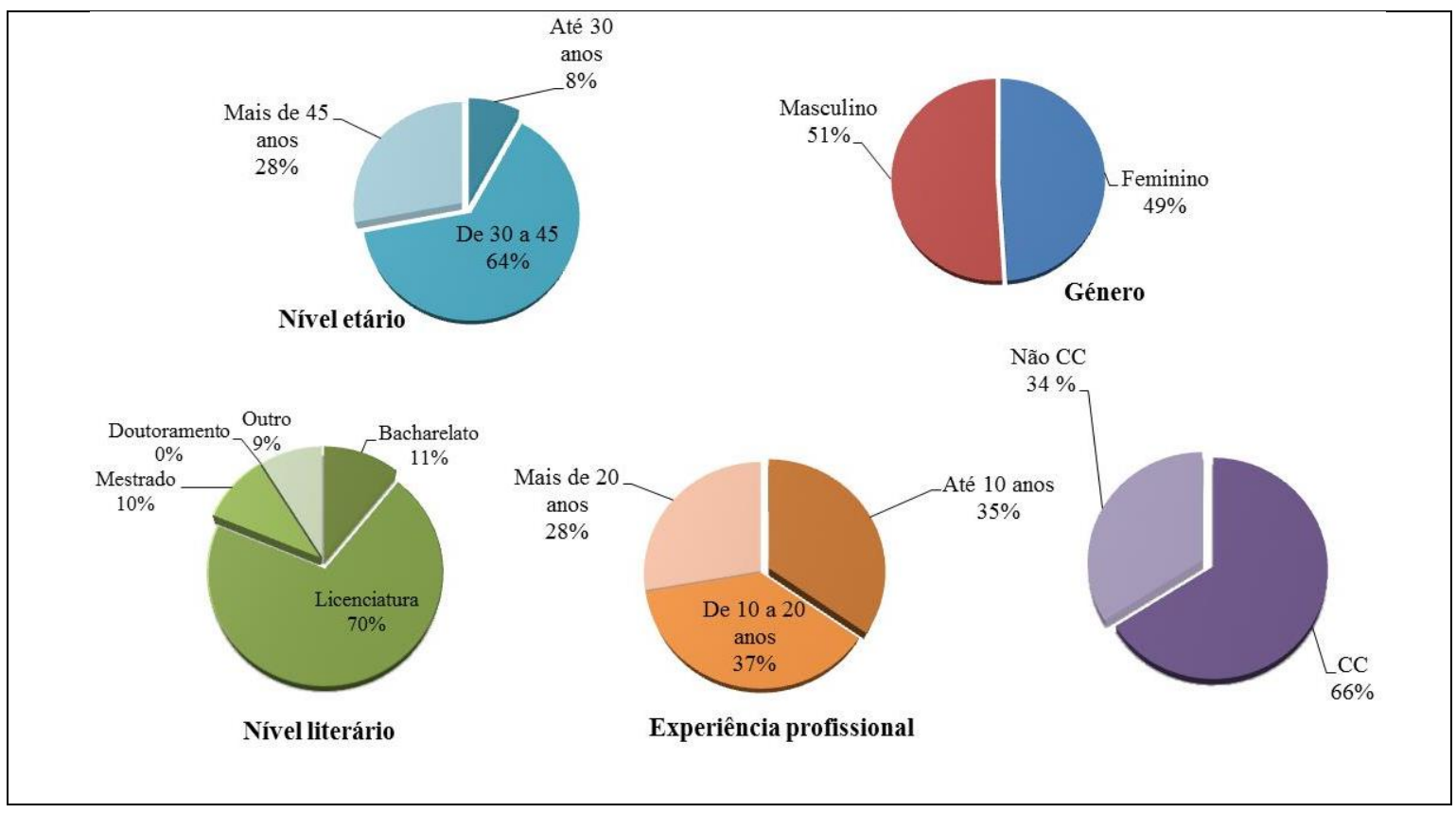

\subsection{Instrumentos}

Colocaram-se um conjunto de questões relacionadas com as orientações éticas de RSE utilizando-se uma escala com 5 categorias $(1,2,3,4$, e 5) indicando a relevância dos motivos apresentados em: irrelevante; pouco relevante; relevante; muito relevante; e totalmente relevante. Na segunda parte do questionário, incluíram-se questões sobre as características dos indivíduos inquiridos, conforme apresentado no Apêndice A - Inquérito Final. Na Figura 6 representa-se o modelo teórico de julgamento sobre as orientações éticas de RSE.

Figura 6. Modelo de orientações éticas de responsabilidade social das empresas

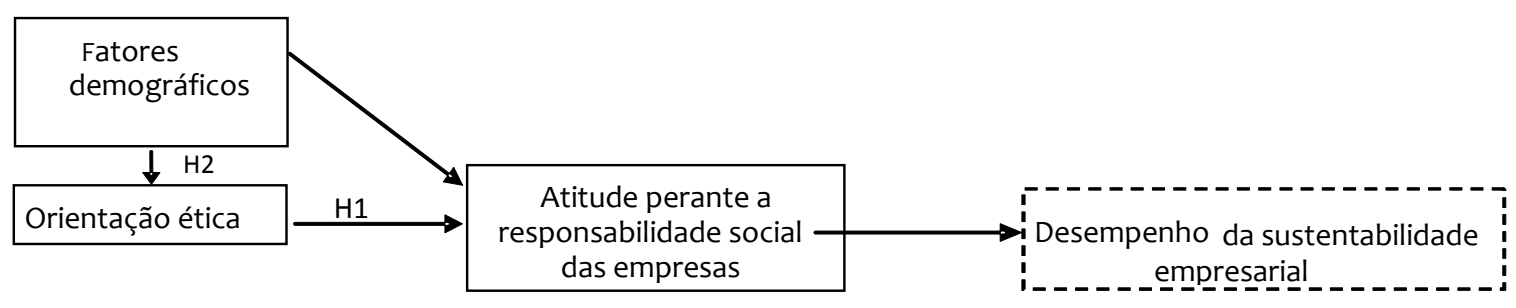

Através do tratamento de dados pretendeu-se analisar a atitude dos contabilistas perante a RSE e a ética. Para o efeito, houve necessidade de recorrer a um conjunto de métodos analíticos. Em primeiro lugar, procedeu-se a uma análise descritiva dos dados das respostas obtidas ao inquérito e procedeu-se à validação dos instrumentos de medida e das escalas utilizadas, tendo-se efetuado o tratamento e a análise estatística, com recurso ao programa estatístico Statistical Package for Social Sciences. 
Com o objetivo de avaliar a orientação ética dos contabilistas, analisaram-se os princípios éticos adotados como critérios nas escolhas ligadas às problemáticas da relação da empresa com a sociedade e suas responsabilidades inerentes. Com base na escala e motivos desenvolvidos por Almeida (2010) e com o objetivo de analisar a orientação ética que influencia a atitude do contabilista perante a RSE, consideraram-se quatro orientações éticas: o utilitarismo; o egoísmo; o absolutismo e o igualitarismo (ligado às teorias da justiça). Assim, a criação das dimensões de ética teve por base teórica o estudo do autor.

O questionário incluiu cinco questões relacionadas com a responsabilidade ética das empresas, em relação às quais foi pedido o nível de relevância face a quatro motivos associados às orientações éticas em análise. À semelhança do elaborado por Almeida (2010) os motivos mantiveram a mesma redação para todas as questões e a escolha das questões teve em consideração os interesses dos diferentes grupos de partes interessadas. Deste modo, evitou-se explicitar a resposta socialmente desejável e o reduzido grau de variabilidade permitindo detetar decisões éticas que não sejam vinculadas apenas a uma única corrente de pensamento, mas que resultam de uma avaliação subjetiva dos contabilistas por vezes contraditórias entre si. O grau de fidelidade do questionário aponta para a consistência interna das perguntas que o constituem. A avaliação foi efetuada através do coeficiente alpha de Cronbach, sendo lícito afirmar que as variáveis em causa são bem explicadas pelas perguntas consideradas, conforme apresentado na Tabela 2.

Tabela 2. Tabela geral do alfa de Cronbach

\begin{tabular}{clcr}
\hline $\begin{array}{c}\text { Componente } \\
\text { Principal }\end{array}$ & Designação Atribuída & Alfa de Cronbach & $\begin{array}{r}\text { Número de } \\
\text { variáveis }\end{array}$ \\
\hline 1 & Utilitarismo & 0,752 & 5 \\
2 & Egoísmo & 0,706 & 5 \\
3 & Justiça & 0,773 & 5 \\
4 & Absolutismo & 0,795 & 5 \\
\hline
\end{tabular}

Na Tabela 3 apresenta-se a estatística das variáveis das dimensões de ética, assim como os níveis de alfa de Cronbach caso se elimine um item das variáveis da dimensão.

Tabela 3. Alfa de Cronbach de dimensões de ética (1/2)

\begin{tabular}{|c|c|c|}
\hline $\begin{array}{c}\text { Dimensão Utilitarismo } \\
\text { - N. }{ }^{\circ} \text { itens 5, alfa de Cronbach 0,75 }\end{array}$ & $\begin{array}{l}\text { Corrected } \\
\text { Item-Total } \\
\text { Correlation }\end{array}$ & $\begin{array}{r}\text { Cronbach's } \\
\text { Alpha if Item } \\
\text { Deleted }\end{array}$ \\
\hline 1.1 A Distribuição de lucros maximiza os benefícios totais. & 0,499 & 0,715 \\
\hline 1.2 A Financiamento de ações sociais maximiza os benefícios totais. & 0,394 & 0,753 \\
\hline $\begin{array}{l}\text { 1.3 A Sustentabilidade com base nos lucros sucessivos maximiza os benefícios } \\
\text { totais. }\end{array}$ & 0,576 & 0,688 \\
\hline 1.4 A Transparência publicitária maximiza os benefícios totais. & 0,562 & 0,692 \\
\hline
\end{tabular}


1.5 A Controlo e prevenção de impactes negativos no meio maximiza os benefícios totais.

Tabela 3. Alfa de Cronbach de dimensões de ética (2/2)

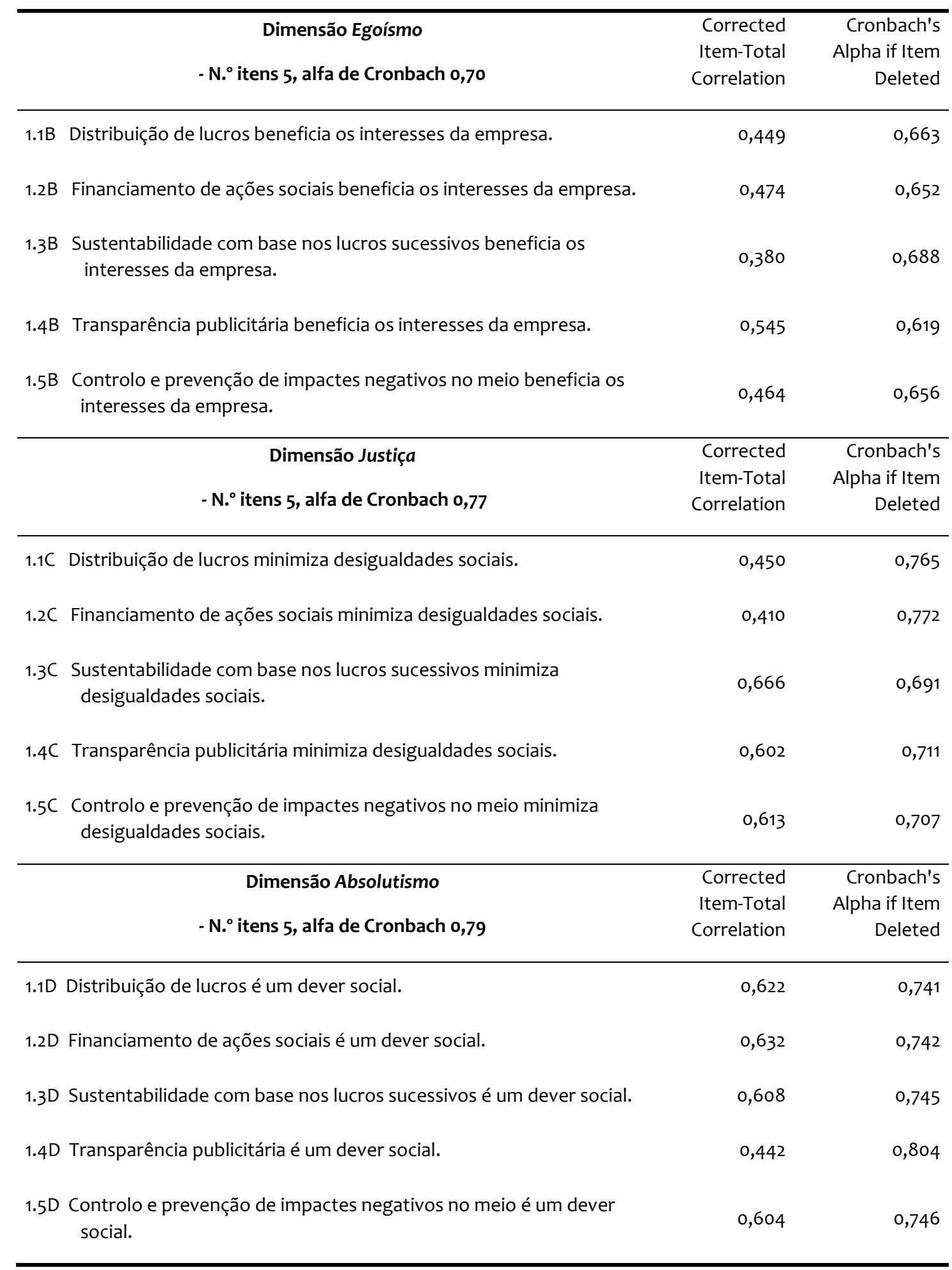




\section{Análise dos resultados}

Na Tabela 4 apresenta-se a média, o desvio padrão, o mínimo e o máximo das quatro dimensões da ética.

Tabela 4. Resultados das dimensões de ética

\begin{tabular}{lrrrr}
\hline \multicolumn{1}{c}{ Dimensões } & Média & D. Padrão & Min. & Max. \\
\hline Utilitarismo & 3,84 & 0,64 & 1 & 5 \\
Egoísmo & 3,65 & 0,63 & 1 & 5 \\
Absolutismo & 3,56 & 0,79 & 1 & 5 \\
Justiça & 3,13 & 0,80 & 1 & 5 \\
\hline
\end{tabular}

Verifica-se que os resultados empíricos obtidos permitem concluir sobre a adequação da escala utilizada e construída com base nos principais referenciais teóricos. Além de permitir identificar as orientações éticas utilitarismo, egoísmo, absolutismo e justiça, os contabilistas revelam uma orientação ética fundada primariamente em princípios utilitaristas com o valor médio superior $X_{m}=3,84$. Embora os contabilistas considerem a maximização dos benefícios totais a principal justificativa moral para o exercício da RSE, também consideram como justificação do compromisso ético das empresas e das ações daí decorrentes os benefícios gerados para a empresa com o valor médio no egoísmo de $X_{m}=3,65$. Os resultados mostram que os contabilistas têm uma visão fundamentalmente consequentalista da RSE, verificandose também uma obrigação moral de contribuir para o bem-estar social, com o valor médio a $\mathrm{X}_{\mathrm{m}}=3,56$ para o absolutismo.

Os contabilistas atribuem menos importância aos benefícios que a RSE pode trazer na diminuição de desigualdades sociais. Além de permitir identificar as orientações éticas utilitarismo, egoísmo, absolutismo e justiça, os contabilistas revelam uma orientação ética fundada primariamente em princípios utilitaristas com o valor médio superior $X_{m}=3,84$. Embora os contabilistas considerem a maximização dos benefícios totais a principal justificativa moral para o exercício da RSE, também consideram como justificação do compromisso ético das empresas e das ações daí decorrentes os benefícios gerados para a empresa com o valor médio no egoísmo de $X_{m}=3,65$. Os resultados mostram que os contabilistas têm uma visão fundamentalmente consequentalista da RSE, verificando-se também uma obrigação moral de contribuir para o bem-estar social, com o valor médio a $\mathrm{X}_{\mathrm{m}}$ = 3,56 para o absolutismo.

Na Tabela 5 apresentam-se a média, o desvio padrão, o mínimo e o máximo das variáveis de ética e das suas dimensões. Para se determinar o valor médio, o desvio padrão, o mínimo e o máximo das quatro dimensões da ética calculou-se uma nova variável para cada uma das dimensões que consiste na média dos casos (ou unidades) que compõem as mesmas e calcularam-se as medidas de estatística descritiva para essa nova variável. São de destacar como valores médios máximos:

- sustentabilidade com base nos lucros sucessivos beneficia os interesses da empresa $\left(X_{m}=4,05\right.$ e $\left.s=0,83\right)$;

- controlo e prevenção de impactes negativos no meio maximiza os benefícios totais para a empresa e para a sociedade $\left(X_{m}=4,02\right.$ e $\left.s=0,80\right)$; 
- sustentabilidade com base nos lucros sucessivos maximiza os benefícios totais para a empresa e para a sociedade $\left(X_{m}=3,89\right.$ e $\left.s=0,86\right)$.

São de destacar como valores médios mínimos:

- transparência publicitária minimiza desigualdades sociais $\left(X_{m}=2,44\right.$ e $\left.s=1,18\right)$;

- controlo e prevenção de impactes negativos no meio minimiza desigualdades sociais $\left(X_{m}=2,85\right.$ e $\left.s=1,15\right)$;

- sustentabilidade com base nos lucros sucessivos minimiza desigualdades sociais $\left(X_{m}=\right.$ $3,05$ e $s=1,06)$.

A principal conclusão a retirar é que os contabilistas parecem considerar que as questões de sustentabilidade e RSE assentam mais em orientações éticas, que consideram a maximização dos benefícios totais a principal justificativa moral para o exercício da RSE. A dimensão da ética utilitarismo que se baseia na aplicação do utilitarismo como princípio moral aplicado ao caso da RSE, justifica o compromisso ético das empresas e das suas ações com base nos benefícios gerados para a empresa e para a sociedade. Esta dimensão origina o valor médio $X_{m}=3,84$ e o desvio padrão $s=0,80$. Nesta dimensão com cinco variáveis, aquela considerada com valor médio maior para maximizar os benefícios totais para a empresa e para a sociedade é o investimento no controlo e prevenção dos impactes negativos da atividade no meio envolvente $\left(X_{m}=4,02\right.$ e $\left.s=0,80\right)$, sendo considerada uma prática muito relevante. A variável considerada com valor médio menor para maximizar os benefícios totais para a empresa e para a sociedade é financiar projetos de solidariedade social $\left(X_{m}=3,64\right.$ e $\mathrm{s}=$ 0,93), sendo, contudo, considerada uma prática relevante a muito relevante. 
Tabela 5. Resultados das dimensões de ética (1/2)

\begin{tabular}{|c|c|c|c|c|c|}
\hline $\begin{array}{c}\text { Dimensões de ética } \\
\text { (1-irrelevante a 5-totalmente relevante) }\end{array}$ & $\mathbf{N}$ & Média & D. Padrão & Min. & Max. \\
\hline Utilitarismo & & 3,84 & 0,64 & 1 & 5 \\
\hline 1.1A Distribuir lucros maximiza os benefícios totais. & 100 & 3,88 & 0,92 & 1 & 5 \\
\hline $\begin{array}{l}\text { 1.2A Financiar ações sociais maximiza os benefícios } \\
\text { totais. }\end{array}$ & 100 & 3,64 & 0,93 & 1 & 5 \\
\hline $\begin{array}{l}\text { 1.3A Sustentabilidade com base nos lucros sucessivos } \\
\text { maximiza os benefícios totais. }\end{array}$ & 100 & 3,89 & 0,86 & 2 & 5 \\
\hline $\begin{array}{l}\text { 1.4A Transparência publicitária maximiza os } \\
\text { benefícios totais. }\end{array}$ & 100 & 3,76 & 0,97 & 1 & 5 \\
\hline $\begin{array}{l}\text { 1.5A Controlo e prevenção de impactes negativos no } \\
\text { meio maximiza os benefícios totais. }\end{array}$ & 100 & 4,02 & 0,80 & 2 & 5 \\
\hline Egoísmo & & 3,65 & 0,63 & 1 & 5 \\
\hline $\begin{array}{l}\text { 1.1B Distribuir lucros beneficia os interesses da } \\
\text { empresa. }\end{array}$ & 100 & 3,55 & 0,95 & 1 & 5 \\
\hline $\begin{array}{l}\text { 1.2B Financiar ações sociais beneficia os interesses } \\
\text { da empresa. }\end{array}$ & 100 & 3,27 & 0,90 & 1 & 5 \\
\hline $\begin{array}{l}\text { 1.3B Sustentabilidade com base nos lucros } \\
\text { sucessivos beneficia os interesses da empresa. }\end{array}$ & 100 & 4,05 & 0,83 & 2 & 5 \\
\hline $\begin{array}{l}\text { 1.4B Transparência publicitária beneficia os } \\
\text { interesses da empresa. }\end{array}$ & 100 & 3,62 & 1,05 & 1 & 5 \\
\hline $\begin{array}{l}\text { 1.5B Controlo e prevenção de impactes negativos no } \\
\text { meio beneficia os interesses da empresa. }\end{array}$ & 100 & 3,75 & 0,91 & 1 & 5 \\
\hline Justiça & & 3,13 & 0,80 & 1 & 5 \\
\hline 1.1C Distribuir lucros minimiza desigualdades sociais. & 100 & 3,46 & 1,18 & 1 & 5 \\
\hline $\begin{array}{l}\text { 1.2C Financiar ações sociais minimiza desigualdades } \\
\text { sociais. }\end{array}$ & 100 & 3,86 & 0,95 & 1 & 5 \\
\hline $\begin{array}{l}\text { 1.3C Sustentabilidade com base nos lucros } \\
\text { sucessivos minimiza desigualdades sociais. }\end{array}$ & 100 & 3,05 & 1,06 & 1 & 5 \\
\hline $\begin{array}{l}\text { 1.4C Transparência publicitária minimiza } \\
\text { desigualdades sociais. }\end{array}$ & 100 & 2,44 & 1,18 & 1 & 5 \\
\hline $\begin{array}{l}\text { 1.5C Controlo e prevenção de impactes negativos no } \\
\text { meio minimiza desigualdades sociais. }\end{array}$ & 100 & 2,85 & 1,15 & 1 & 5 \\
\hline Absolutismo & & 3,56 & 0,79 & 1 & 5 \\
\hline 1.1D Distribuir lucros é um dever social. & 100 & 3,64 & 1,03 & 1 & 5 \\
\hline 1.2D Financiar ações sociais é um dever social. & 100 & 3,73 & 0,93 & 1 & 5 \\
\hline $\begin{array}{l}\text { 1.3D Sustentabilidade com base nos lucros } \\
\text { sucessivos é um dever social. }\end{array}$ & 100 & 3,26 & 1,10 & 1 & 5 \\
\hline 1.4D Transparência publicitária é um dever social. & 100 & 3,39 & 1,20 & 1 & 5 \\
\hline $\begin{array}{l}\text { 1.5D Controlo e prevenção de impactes negativos no } \\
\text { meio é um dever social. }\end{array}$ & 100 & 3,79 & 1,07 & 1 & 5 \\
\hline
\end{tabular}


A dimensão ética referente ao egoísmo que se baseia na aplicação do egoísmo ético como princípio moral aplicado ao caso da RSE, justifica o compromisso ético das empresas e das suas ações com base nos interesses e nos benefícios gerados para a empresa. Esta dimensão origina o valor médio $X_{m}=3,64$ e o desvio padrão $s=0,63$. Nesta dimensão com cinco variáveis, aquela considerada com valor médio maior para beneficiar os interesses da empresa é a sustentabilidade com base na obtenção de lucros sucessivos, indicando ser considerada uma prática muito relevante $\left(X_{m}=4,05\right.$ e $\left.s=0,83\right)$. A variável considerada com valor médio menor para beneficiar os interesses da empresa é financiar projetos de solidariedade social $\left(X_{m}=3,27\right.$ e $\left.s=0,90\right)$, sendo considerada uma prática relevante.

A dimensão ética referente à justiça que se baseia na aplicação da justiça distributiva como princípio moral aplicado ao caso da RSE, justifica o compromisso ético das empresas e das suas ações com base nas teorias de justiça distributiva de forma a reforçar a desigualdade social e beneficiar os menos favorecidos. Esta dimensão origina o valor médio $X_{m}=3,30$ e o desvio padrão $s=0,80$, indicando, como anteriormente referido, que os contabilistas atribuem menos importância aos benefícios que a RSE pode trazer na diminuição de desigualdades sociais. Nesta dimensão com cinco variáveis, aquela considerada com valor médio maior para contribuir para minimizar desigualdades sociais é financiar projetos de solidariedade social $\left(X_{m}=3,86\right.$ e $\left.\mathrm{s}=0,95\right)$, sendo considerada uma prática relevante a muito relevante. A variável considerada com valor médio menor para contribuir para minimizar desigualdades sociais é fazer publicidade transparente dos produtos quanto aos riscos e às imperfeições que estes possam apresentar para os clientes $\left(X_{m}=2,44\right.$ e $\left.s=1,18\right)$, sendo considerada uma prática pouco relevante.

A dimensão ética referente ao absolutismo que se baseia na aplicação do absolutismo como princípio moral aplicado ao caso da RSE, justifica o compromisso ético das empresas e das suas ações com base na obrigação moral que as empresas têm de contribuir para o bemestar social. Esta dimensão origina o valor médio $X_{m}=3,56$ e o desvio padrão $s=0,79$, indicando que os contabilistas parecem reconhecer que as empresas têm uma obrigação de contribuir para o bem-estar social. Nesta dimensão com cinco variáveis, aquela considerada como dever de agir em função do bem-estar social com valor médio maior é o investimento no controlo e prevenção dos impactes negativos da atividade no meio envolvente $\left(X_{m}=3,79\right.$ e $s=1,07)$, sendo considerada uma prática relevante a muito relevante. A variável considerada como dever de agir em função do bem-estar social com valor médio menor é a sustentabilidade com base na obtenção de lucros sucessivos $\left(X_{m}=3,26\right.$ e $\left.s=1,10\right)$, sendo, contudo, considerada uma prática relevante.

No Apêndice B: Resultados da Investigação Empírica, apresenta-se a estatística descritiva das variáveis de orientação ética e na Tabela 6 apresentam-se os resultados referentes à caracterização da empresa em termos de empenho ético, na perspetiva do contabilista. 
Tabela 6. Estatística descritiva do empenho ético percecionado pelo contabilista

\begin{tabular}{|c|c|c|c|}
\hline Caraterização da empresa na perspetiva do contabilista & Sim & Não & NS/NR \\
\hline 2.6 A empresa tem um código de ética? & $94 \%$ & $1 \%$ & $5 \%$ \\
\hline $\begin{array}{l}\text { 2.7 A empresa assume as orientações do código de ética? (se respondeu } \\
\text { não na resposta anterior, escolha NS/NR) }\end{array}$ & $88 \%$ & $1 \%$ & $11 \%$ \\
\hline $\begin{array}{l}\text { 2.8 Na empresa, os empregados podem denunciar comportamentos não } \\
\text { éticos de forma anónima? }\end{array}$ & $62 \%$ & $14 \%$ & $25 \%$ \\
\hline $\begin{array}{l}\text { 2.9 A empresa tem sistema de avaliação de ética medido por entidade } \\
\text { independente? }\end{array}$ & $26 \%$ & $32 \%$ & $41 \%$ \\
\hline $\begin{array}{l}\text { 2.10 A empresa tem um sistema disciplinar onde comportamentos não } \\
\text { éticos são punidos? }\end{array}$ & $57 \%$ & $11 \%$ & $32 \%$ \\
\hline 2.11 A empresa proporciona formação/seminários em ética? & $53 \%$ & $25 \%$ & $22 \%$ \\
\hline $\begin{array}{l}\text { 2.12 A empresa disponibiliza, com regularidade, parte significante dos lucros } \\
\text { para solidariedade social? }\end{array}$ & $69 \%$ & $20 \%$ & $12 \%$ \\
\hline $\begin{array}{l}\text { 2.13 A empresa desenvolve ações de solidariedade social que permitem a } \\
\text { participação dos empregados? }\end{array}$ & $83 \%$ & $12 \%$ & $5 \%$ \\
\hline 2.14 A empresa tem um departamento de ética? & $23 \%$ & $45 \%$ & $32 \%$ \\
\hline 2.15 A empresa tem uma comissão de ética? & $43 \%$ & $18 \%$ & $39 \%$ \\
\hline
\end{tabular}

Quanto aos resultados mais relevantes, verifica-se que $94 \%$ dos contabilistas indicam que a empresa onde exercem funções tem código de ética, sendo que $88 \%$ concordam que a empresa assume as orientações do código de ética. Quando questionados sobre se a empresa tem um sistema de avaliação de ética medido por entidade independente, $32 \%$ indicam que não, sendo que $41 \%$ não sabe ou não responde. Verifica-se que $69 \%$ dos contabilistas indicam que as empresas disponibilizam, com regularidade, uma parte significante dos seus lucros para projetos de solidariedade social e que $83 \%$ indicam que a empresa desenvolve ações que permitem aos empregados participarem em ações voluntárias de solidariedade social. Na Tabela 7 apresentam-se os resultados referentes às características pessoais do contabilista e à sua perceção sobre o empenho ético da empresa onde está inserido. 
Tabela 7. Estatística descritiva do empenho ético percecionado sobre caraterísticas pessoais

\begin{tabular}{|c|c|c|c|c|c|c|c|c|}
\hline \multirow{3}{*}{$\begin{array}{l}\text { Caraterização das empresas na perspetiva dos } \\
\text { contabilistas }\end{array}$} & \multicolumn{4}{|c|}{ Contabilistas } & \multicolumn{4}{|c|}{ Género } \\
\hline & \multicolumn{2}{|c|}{ Certificado } & \multicolumn{2}{|c|}{$\begin{array}{l}\text { Não } \\
\text { Certificado }\end{array}$} & \multicolumn{2}{|c|}{ Feminino } & \multicolumn{2}{|c|}{ Masculino } \\
\hline & Sim & Não & Sim & Não & Sim & Não & Sim & Não \\
\hline 2.6 A empresa tem um código de ética? & $92 \%$ & $2 \%$ & $97 \%$ & $0 \%$ & $98 \%$ & $0 \%$ & $90 \%$ & $2 \%$ \\
\hline $\begin{array}{l}\text { 2.7 A empresa assume as orientações do código } \\
\text { de ética? (se respondeu não na resposta } \\
\text { anterior, escolha NS/NR) }\end{array}$ & $89 \%$ & $2 \%$ & $86 \%$ & $0 \%$ & $94 \%$ & $0 \%$ & $82 \%$ & $2 \%$ \\
\hline $\begin{array}{l}\text { 2.8 Na empresa, os empregados podem denunciar } \\
\text { comportamentos não éticos de forma } \\
\text { anónima? }\end{array}$ & $65 \%$ & $14 \%$ & $58 \%$ & $11 \%$ & $69 \%$ & $8 \%$ & $57 \%$ & $18 \%$ \\
\hline $\begin{array}{l}\text { 2.9 A empresa tem sistema de avaliação de ética } \\
\text { medido por entidade independente? }\end{array}$ & $23 \%$ & $35 \%$ & $33 \%$ & $25 \%$ & $33 \%$ & $18 \%$ & $22 \%$ & $45 \%$ \\
\hline $\begin{array}{l}\text { 2.10.A empresa tem um sistema disciplinar onde } \\
\text { comportamentos não éticos são punidos? }\end{array}$ & $55 \%$ & $11 \%$ & $58 \%$ & $11 \%$ & $55 \%$ & $6 \%$ & $59 \%$ & $16 \%$ \\
\hline $\begin{array}{l}\text { 2.11 A empresa proporciona formação/seminários } \\
\text { em ética? }\end{array}$ & $54 \%$ & $31 \%$ & $50 \%$ & $17 \%$ & $65 \%$ & $12 \%$ & $41 \%$ & $39 \%$ \\
\hline $\begin{array}{l}\text { 2.12 A empresa disponibiliza, com regularidade, } \\
\text { parte significante dos lucros para } \\
\text { solidariedade social? }\end{array}$ & $63 \%$ & $25 \%$ & $78 \%$ & $11 \%$ & $80 \%$ & $8 \%$ & $57 \%$ & $31 \%$ \\
\hline $\begin{array}{l}\text { 2.13 A empresa desenvolve ações de solidariedade } \\
\text { social que permitem a participação dos } \\
\text { empregados? }\end{array}$ & $80 \%$ & $15 \%$ & $89 \%$ & $6 \%$ & $96 \%$ & $2 \%$ & $71 \%$ & $22 \%$ \\
\hline 2.14 A empresa tem um departamento de ética? & $20 \%$ & $54 \%$ & $25 \%$ & $31 \%$ & $31 \%$ & $29 \%$ & $14 \%$ & $63 \%$ \\
\hline 2.15 A empresa tem uma comissão de ética? & $45 \%$ & $23 \%$ & $39 \%$ & $8 \%$ & $39 \%$ & $12 \%$ & $47 \%$ & $24 \%$ \\
\hline
\end{tabular}

Verifica-se, por um lado, que os contabilistas Certificados parecem estar a trabalhar em empresas com menor empenho ético uma vez que indicam que as empresas onde exercem as suas funções têm em média menor empenho ético que os restantes contabilistas que não são certificados. Por outro lado, constata-se que os contabilistas do género feminino parecem estar a trabalhar em empresas com maior empenho ético que os do género masculino.

\section{Conclusão}

Conclui-se que a ética empresarial está diretamente relacionada com o comportamento ético e socialmente responsável dos empregados e apela-se à reflexão sobre os conceitos de ética e RSE, para procurar os seus fundamentos. Assim, os comportamentos empresariais deverão ser questionados e avaliados quanto à sua adequação em termos das responsabilidades das empresas perante a sociedade. Propõe-se uma conceção de RSE baseada no pressuposto de que as empresas e a sociedade não são entidades independentes, nem com existência intrínseca, mas sim interligadas e cuja relação origina expectativas lícitas na sociedade. A RSE vê-se dirigida pelos modelos desenvolvidos pelos indivíduos que integram as empresas, 
representando a relação que estes pretendem que a empresa desenvolva com a sociedade. Tendo em conta que as empresas são dotadas com um certo grau de existência autónoma, que lhes dá a liberdade e possibilidade de serem éticas, a ética empresarial é parte da ética aplicada, que, reflexivamente, evidencia como aplicar os princípios éticos à atividade empresarial, estuda os comportamentos e as decisões empresariais com impacto no bemestar individual e social. Através dos muitos pontos de contacto entre a ética e a RSE, é possível condicionar a generalidade dos comportamentos empresariais e analisar a forma como a empresa atinge os seus objetivos, os meios que utiliza e o bem-estar que proporciona à sua volta, não se questionando o objetivo das empresas serem lucrativas, mas sim a forma como estas atuam na sociedade.

Os contabilistas apresentam diferentes atitudes e posições perante a RSE associadas a diferentes teorias da RSE e em função de diferentes orientações éticas. Quanto às orientações éticas dos contabilistas, perante a RSE, verifica-se que nem todos os contabilistas parecem aperceber-se das implicações das suas intuições éticas e que a maior parte dos contabilistas revelam uma orientação ética fundada primariamente em princípios utilitaristas, considerando como justificação do compromisso ético das empresas e das ações daí decorrentes, os benefícios gerados para a empresa, mas também uma obrigação moral de contribuir para o bem-estar social. Deste modo, os contabilistas têm uma visão fundamentalmente consequentalista da RSE e atribuem menos importância aos benefícios que a RSE pode trazer na diminuição de desigualdades sociais. É possível que nem todos os contabilistas se estejam a aperceber das implicações das suas intuições éticas, verificando-se que a variável género parece estar a influenciar tendencionalmente a definição da orientação ética dos contabilistas.

\section{Referências bibliográficas}

Almeida, F. (2010). Ética, valores humanos e responsabilidade social das empresas. Lisboa: Princípia.

Alvesson, M. \& Willmott, H. (1992). Critical theory and management studies: An introduction. Critical Management Studies (pp. 1-20). London: Sage.

Aristóteles. (2009). Ética a nicómaco (A. C. Caeiro, trad.). Lisboa: Quetzal. (Originalmente publicado em 1837).

Caldeira, I. (2009). Ética empresarial: Uma fundamentação teórica (Dissertação de mestrado não publicada). Faculdade de Letras da Universidade de Lisboa, Lisboa.

Callicott, J. B. (1989). In defense of the land ethic: Essays in environmental philosophy. Albany: SUNY series in Philosophy and Biology.

Callicott, J. B. \& Frodeman, R. (Eds.) (2009). Encyclopedia of environmental ethics and philosophy. New York: Macmillan.

Carroll, A. B. (1979). A three-dimensional conceptual model of corporate performance. Academy of Management Review, 4 (4), 497-505.

Carroll, A. B. (1999). Corporate social responsibility: Evolution of a definitional construct. Business \& Society, 38 (3), 268-295.

Carvalho, J. A. (2011). Ética e liderança: A crise no sector imobiliário. Lisboa: Imoedições.

Comissão das Comunidades Europeias (2001). Livro Verde: Promover um quadro europeu para a responsabilidade social das empresas. Bruxelas: Comissão das Comunidades Europeias.

Cortina, A., Conill, J., Moratalla, A. D. \& Marzá, V. D. G. (2005). Ética de la empresa: Claves para una nueva cultura empresarial. Madrid: Editorial trotta.

Costa, M. A. N. (2005). Fazer o bem compensa? Uma reflexão sobre a responsabilidade social empresarial. Revista Crítica de Ciências Sociais, 73, 67-89.

Felix, A. B. (2011). A crise económica e a ética. Inforbanca, 90, 4-6. 
Friedman, M. (1970, 13 setembro). The social responsibility of business is to increase its profits. The New York Times Magazine, p.17.

Kant, I. (2015). Fundamentação da metafísica dos costumes (Trad. P. Galvão). Lisboa: Edições 70. (Originalmente publicado em 1785).

Leopold, A. (1949). A sand county almanac and sketches here and there. Oxford: Oxford University Press.

Matthew H., Bradley L. \& Sutton, S. G. (2016.) Potential employees' ethical perceptions of active monitoring: The dark side of data analytics. Journal of Information Systems In-Press. doi: http://dx.doi.org/10.2308/isys-51580

Meredith B. L., Bernardi R. A. \& Bosco S. M. (2013). Does female representation on boards of directors associate with increased transparency and ethical behavior? Accounting and the Public Interest, 13 (1), 132-150. doi: http://dx.doi.org/10.2308/apin-10374

Minoja, M. (2012). Stakeholder management theory, firm strategy and ambidexterity. Journal of Business Ethics, 109 (1), 67-82. doi: 10.1007/s10551-012-1380-9

Rego, A., Cunha, M. P. E., Costa, N. G. D., Gonçalves, H. \& Cabral-Cardoso, C. (2007). Gestão ética e socialmente responsável. Lisboa: $\mathrm{RH}$.

Regojo, P. (2005). Ética e direção de empresa: Reflexões a partir dos ensinamentos da igreja. Lisboa: Edições AESE.

Rocha, A. da S. (2010). Ética, deontologia e responsabilidade social. Porto: Vida Económica.

Rolston, H. (1988). Environmental ethics. Philadelphia: Temple University Press.

Rawls, J. (1971). A theory of justice. Cambridge, Massachusetts: Harvard University Press.

Schwartz, M. S. \& Carroll, A. B. (2003). Corporate social responsability: A three-domain approach. Business Ethics Quartely, 13 (4), 503-530.

Simões, M. C. (2016) Filosofia moral de John Stuart Mill: Utilitarismo e liberalismo. São Paulo: Editora Ideias e Letras.

Sims, R. R. (2003). Ethics and corporate social responsibility: Why giants fall. Westport, Connecticut: Greenwood Publishing Group.

World Business Council for Sustainable Development (2000). Corporate social responsibility: Making good business sense. Geneve.

Wu, M. (2013). Towards a stakeholder perspective on competitive advantage. International Journal of Business and Management, 8 (4), 20-29. doi: http://dx.doi.org/10.5539/ijbm.v8n4p2o 
TÂNIA ALVES DE JESUS é professora no ISCAL, Doutorada em Gestão com especialização em Contabilidade pela Universidade Lusíadas e Mestre em Contabilidade pelo ISCTE. Autora de vários artigos e de livros sobre SNC e Normas Internacionais de Contabilidade, com vasta experiência no ensino da Contabilidade Financeira. Endereço institucional: Instituto Superior de Contabilidade e Administração, Av. Miguel Bombarda, 20, 1050-053 Lisboa, Portugal.

MANUELA SARMENTO é professora catedrática de gestão na Academia Militar (AM) e na Universidade Lusíada (UL). Na AM é presidente da comissão científica do Mestrado Integrado em Administração e regente de Gestão de Recursos Humanos e Seminários Avançados em Liderança. Na UL é regente de Metodologia Científica no Mestrado "Gestão de Recursos Humanos". Publicou 11 livros, 200 artigos e capítulos com arbitragem científica. Foi presidente dos Centros de Investigação: Cinamil e CITIS. É avaliadora de projetos da UE, Itália e Grécia. Foi presidente da direção da Associação Portuguesa de Management. Endereço institucional: Academia Militar - Instituto Universitário Militar, Av. Castro Guimarães, 2720-113, Amadora, Portugal.

MANUELA DUARTE é doutorada em gestão e professora coordenadora de contabilidade do Instituto Superior de Contabilidade e Administração de Lisboa, foi professora associada (convidada) da Universidade Lusíada durante vários anos tendo sido regente de contabilidade financeira nas licenciaturas em gestão, economia, turismo e solicitadoria. Publicou três livros e vários manuais de apoio. Cerca de 150 artigos e capítulos de livros com arbitragem científica. Foi presidente do conselho diretivo do ISCAL. Endereço institucional: Instituto Superior de Contabilidade e Administração, Av. Miguel Bombarda, 20, 1050-053 Lisboa, Portugal.

Submetido em 26 maio 2016

Aceite em 31 janeiro 2017 


\section{Apêndice A. Inquérito final}

\section{ORIENTAÇÃO ÉTICA E RESPONSABILIDADE SOCIAL}

Indique a relevância que atribui a cada um dos motivos apresentados, assinalando a sua opinião em todas as opções. Para a resposta, considere, por favor a escala: 1 - Irrelevante; 2 - Pouco relevante; 3Relevante; 4 - Muito relevante, 5 - Totalmente relevante.

\begin{tabular}{|c|c|c|c|c|c|}
\hline \multicolumn{7}{|c|}{ Irrelevante (1) a Totalmente relevante (5) } \\
\hline A. Maximiza os benefícios totais (para a empresa e para a sociedade) & 1 & 2 & 3 & 4 & 5 \\
\hline B. Beneficia os interesses da empresa & 1 & 2 & 3 & 4 & 5 \\
\hline C. Contribui para minimizar desigualdades sociais & 1 & 2 & 3 & 4 & 5 \\
\hline D. A empresa tem o dever de agir em função do bem-estar social & 1 & 2 & 3 & 4 & 5 \\
\hline
\end{tabular}

1.2 Financiar projetos de solidariedade social é uma prática aceitável porque:

Irrelevante (1) a Totalmente relevante (5)

A. Maximiza os benefícios totais (para a empresa e para a sociedade)

B. Beneficia os interesses da empresa

C. Contribui para minimizar desigualdades sociais

D. A empresa tem o dever de agir em função do bem-estar social

\begin{tabular}{|l|l|l|l|l|}
\hline 1 & 2 & 3 & 4 & 5 \\
\hline 1 & 2 & 3 & 4 & 5 \\
\hline 1 & 2 & 3 & 4 & 5 \\
\hline 1 & 2 & 3 & 4 & 5 \\
\hline
\end{tabular}

1.3 A sustentabilidade com base na obtenção de lucros sucessivos é uma prática aceitável porque: Irrelevante (1) a Totalmente relevante (5)

\begin{tabular}{|c|c|c|c|c|c|}
\hline A. Maximiza os benefícios totais (para a empresa e para a sociedade) & 1 & 2 & 3 & 4 & 5 \\
\hline B. Beneficia os interesses da empresa & 1 & 2 & 3 & 4 & 5 \\
\hline C. Contribui para minimizar desigualdades sociais & 1 & 2 & 3 & 4 & 5 \\
\hline D. A empresa tem o dever de agir em função do bem-estar social & 1 & 2 & 3 & 4 & 5 \\
\hline
\end{tabular}

1.4 Fazer publicidade transparente dos produtos quanto aos riscos e imperfeições que estes possam apresentar para os clientes, é uma prática aceitável porque:

Irrelevante (1) a Totalmente relevante (5)

A. Maximiza os benefícios totais (para a empresa e para a sociedade)

B. Beneficia os interesses da empresa

C. Contribui para minimizar desigualdades sociais

D. A empresa tem o dever de agir em função do bem-estar social

\begin{tabular}{|c|c|c|c|c|}
\hline 1 & 2 & 3 & 4 & 5 \\
\hline 1 & 2 & 3 & 4 & 5 \\
\hline 1 & 2 & 3 & 4 & 5 \\
\hline 1 & 2 & 3 & 4 & 5 \\
\hline
\end{tabular}

1.5 Investir no controlo e prevenção dos impactes negativos da atividade no meio envolvente, é uma prática aceitável porque:

Irrelevante (1) a Totalmente relevante (5)

A. Maximiza os benefícios totais (para a empresa e para a sociedade)

B. Beneficia os interesses da empresa

\begin{tabular}{|l|l|l|l|l|}
\hline 1 & 2 & 3 & 4 & 5 \\
\hline 1 & 2 & 3 & 4 & 5 \\
\hline
\end{tabular}




\begin{tabular}{|c|c|c|c|c|c|}
\hline C. Contribui para minimizar desigualdades sociais & 1 & 2 & 3 & 4 & 5 \\
\hline D. A empresa tem o dever de agir em função do bem-estar social & 1 & 2 & 3 & 4 & 5 \\
\hline
\end{tabular}

\section{CARACTERIZAÇÃO DO RESPONDENTE E DA EMPRESA ONDE DESEMPENHA FUNÇÕES}

\begin{tabular}{|l|l|}
\hline 2.1 Ano de nascimento & \\
\hline \multirow{2}{*}{2.2 Género } & $\square$ Feminino $\square$ Masculino \\
\hline & $\square$ Bacharelato \\
& \\
2.3 Nível de escolaridade & $\square$ Licenciatura \\
& $\square$ Mestrado \\
& $\square$ Doutoramento \\
& $\square$ Outro \\
\hline 2.4 Anos de experiência profissional em contabilidade & $\square$ Sim $\square$ Não \\
\hline 2.5 Contabilista Certificado & $\square$ M \\
\hline
\end{tabular}

\begin{tabular}{|c|l|}
\hline 2.6 A empresa tem um código de ética? & $\square$ Sim $\square$ Não $\square$ NS / NR \\
\hline $\begin{array}{c}\text { 2.7 A empresa assume as orientações do código de ética? (se respondeu não } \\
\text { na resposta anterior, escolha NS/NR) }\end{array}$ & $\square$ Sim $\square$ Não $\square$ NS / NR \\
\hline $\begin{array}{l}\text { 2.8 Na empresa, os empregados podem denunciar comportamentos não } \\
\text { éticos de forma anónima? }\end{array}$ & $\square$ Sim $\square$ Não $\square$ NS / NR \\
\hline $\begin{array}{l}\text { 2.9 A empresa tem sistema de avaliação de ética medido por entidade } \\
\text { independente? }\end{array}$ & $\square \operatorname{Sim~} \square$ Não $\square$ NS / NR \\
\hline $\begin{array}{l}\text { 2.10. A empresa tem um sistema disciplinar onde comportamentos não } \\
\text { éticos são punidos? }\end{array}$ & $\square \operatorname{Sim~} \square$ Não $\square$ NS / NR \\
\hline $\begin{array}{l}\text { 2.11 A empresa proporciona formação/seminários em ética? } \\
\text { 2.12 A empresa disponibiliza, com regularidade, uma parte significante dos } \\
\text { seus lucros para projetos de solidariedade social? }\end{array}$ & $\square \operatorname{Sim~} \square$ Não $\square$ NS / NR \\
\hline $\begin{array}{c}\text { 2.13 A empresa desenvolve ações que permitem aos empregados } \\
\text { participarem em ações voluntárias de solidariedade social? }\end{array}$ & $\square$ NS / NR \\
\hline 2.14 A empresa tem um departamento de ética? & $\square \operatorname{Sim~} \square$ Não $\square$ NS / NR \\
\hline 2.15 A empresa tem uma comissão de ética? & $\square \operatorname{Sim~} \square$ Não $\square$ NS / NR \\
\hline
\end{tabular}


Apêndice B. Resultados da investigação empírica

Estatística descritiva das variáveis de orientação Ética (1/2)

\begin{tabular}{|c|c|c|c|c|c|}
\hline 1.1 Distribuir lucros aos empregados: & Irrelevante & $\begin{array}{l}\text { Pouco } \\
\text { relevante }\end{array}$ & Relevante & $\begin{array}{l}\text { Muito } \\
\text { relevante }\end{array}$ & $\begin{array}{l}\text { Totalmente } \\
\text { relevante }\end{array}$ \\
\hline $\begin{array}{l}\text { A. Maximiza os benefícios totais (para a } \\
\text { empresa e para a sociedade) }\end{array}$ & $2 \%$ & $5 \%$ & $21 \%$ & $44 \%$ & $28 \%$ \\
\hline B. Beneficia os interesses da empresa & $3 \%$ & $7 \%$ & $37 \%$ & $37 \%$ & $17 \%$ \\
\hline $\begin{array}{l}\text { C. Contribui para minimizar desigualdades } \\
\text { sociais }\end{array}$ & $9 \%$ & $12 \%$ & $22 \%$ & $36 \%$ & $21 \%$ \\
\hline $\begin{array}{l}\text { D. A empresa tem o dever de agir em } \\
\text { função do bem-estar social }\end{array}$ & $5 \%$ & $8 \%$ & $28 \%$ & $38 \%$ & $22 \%$ \\
\hline $\begin{array}{l}\text { 1.2 Financiar projetos de solidariedade } \\
\text { social: }\end{array}$ & Irrelevante & $\begin{array}{l}\text { Pouco } \\
\text { relevante }\end{array}$ & Relevante & $\begin{array}{l}\text { Muito } \\
\text { relevante }\end{array}$ & $\begin{array}{l}\text { Totalmente } \\
\text { relevante }\end{array}$ \\
\hline $\begin{array}{l}\text { A. Maximiza os benefícios totais (para a } \\
\text { empresa e para a sociedade) }\end{array}$ & $2 \%$ & $8 \%$ & $36 \%$ & $33 \%$ & $22 \%$ \\
\hline B. Beneficia os interesses da empresa & $3 \%$ & $14 \%$ & $44 \%$ & $28 \%$ & $11 \%$ \\
\hline $\begin{array}{l}\text { C. Contribui para minimizar desigualdades } \\
\text { sociais }\end{array}$ & $2 \%$ & $5 \%$ & $25 \%$ & $38 \%$ & $31 \%$ \\
\hline $\begin{array}{l}\text { D. A empresa tem o dever de agir em } \\
\text { função do bem-estar social }\end{array}$ & $2 \%$ & $8 \%$ & $29 \%$ & $38 \%$ & $24 \%$ \\
\hline $\begin{array}{l}\text { 1.3 A sustentabilidade com base na } \\
\text { obtenção de lucros sucessivos: }\end{array}$ & Irrelevante & $\begin{array}{l}\text { Pouco } \\
\text { relevante }\end{array}$ & Relevante & $\begin{array}{l}\text { Muito } \\
\text { relevante }\end{array}$ & $\begin{array}{l}\text { Totalmente } \\
\text { relevante }\end{array}$ \\
\hline $\begin{array}{l}\text { A. Maximiza os benefícios totais (para a } \\
\text { empresa e para a sociedade) }\end{array}$ & $1 \%$ & $3 \%$ & $34 \%$ & $33 \%$ & $30 \%$ \\
\hline B. Beneficia os interesses da empresa & $1 \%$ & $1 \%$ & $28 \%$ & $34 \%$ & $37 \%$ \\
\hline $\begin{array}{l}\text { C. Contribui para minimizar desigualdades } \\
\text { sociais }\end{array}$ & $8 \%$ & $22 \%$ & $36 \%$ & $24 \%$ & $11 \%$ \\
\hline $\begin{array}{l}\text { D. A empresa tem o dever de agir em } \\
\text { função do bem-estar social }\end{array}$ & $9 \%$ & $13 \%$ & $33 \%$ & $31 \%$ & $14 \%$ \\
\hline
\end{tabular}




\section{Estatística descritiva das variáveis de orientação Ética (2/2)}

\begin{tabular}{|c|c|c|c|c|c|}
\hline $\begin{array}{l}\text { 1.4 Fazer publicidade transparente dos } \\
\text { produtos quanto aos riscos e } \\
\text { imperfeições que estes possam } \\
\text { apresentar para os clientes: }\end{array}$ & Irrelevante & $\begin{array}{l}\text { Pouco } \\
\text { relevante }\end{array}$ & Relevante & $\begin{array}{l}\text { Muito } \\
\text { relevante }\end{array}$ & $\begin{array}{l}\text { Totalmente } \\
\text { relevante }\end{array}$ \\
\hline $\begin{array}{l}\text { A. Maximiza os benefícios totais (para a } \\
\text { empresa e para a sociedade) }\end{array}$ & $2 \%$ & $8 \%$ & $31 \%$ & $33 \%$ & $27 \%$ \\
\hline B. Beneficia os interesses da empresa & $2 \%$ & $16 \%$ & $23 \%$ & $34 \%$ & $25 \%$ \\
\hline $\begin{array}{l}\text { C. Contribui para minimizar desigualdades } \\
\text { sociais }\end{array}$ & $25 \%$ & $32 \%$ & $22 \%$ & $13 \%$ & $8 \%$ \\
\hline $\begin{array}{l}\text { D. A empresa tem o dever de agir em função } \\
\text { do bem-estar social }\end{array}$ & $9 \%$ & $14 \%$ & $27 \%$ & $29 \%$ & $21 \%$ \\
\hline $\begin{array}{l}1.5 \text { Investir no controlo e prevenção dos } \\
\text { impactes negativos da atividade no } \\
\text { meio envolvente: }\end{array}$ & Irrelevante & $\begin{array}{l}\text { Pouco } \\
\text { relevante }\end{array}$ & Relevante & $\begin{array}{l}\text { Muito } \\
\text { relevante }\end{array}$ & $\begin{array}{l}\text { Totalmente } \\
\text { relevante }\end{array}$ \\
\hline $\begin{array}{l}\text { A. Maximiza os benefícios totais (para a } \\
\text { empresa e para a sociedade) }\end{array}$ & $1 \%$ & $3 \%$ & $22 \%$ & $44 \%$ & $30 \%$ \\
\hline B. Beneficia os interesses da empresa & $3 \%$ & $5 \%$ & $30 \%$ & $41 \%$ & $21 \%$ \\
\hline $\begin{array}{l}\text { C. Contribui para minimizar desigualdades } \\
\text { sociais }\end{array}$ & $15 \%$ & $25 \%$ & $29 \%$ & $23 \%$ & $8 \%$ \\
\hline $\begin{array}{l}\text { D. A empresa tem o dever de agir em função } \\
\text { do bem-estar social }\end{array}$ & $6 \%$ & $5 \%$ & $23 \%$ & $38 \%$ & $28 \%$ \\
\hline
\end{tabular}

